\title{
1 Korintiërs 9:24-27 - Kerklike leierskap vra 'n besondere vorm van selfbeheersing
}

D S M Bredenkamp ${ }^{1}$

(Universiteit van Pretoria)

\section{ABSTRACT}

\section{Corinthians 9:24-27 - Church leadership requires a unique type of self-control}

The purpose of this article is to describe Paul's self-control in 1 Corinthians 9 as an example to contemporary church leaders. After ascertaining the framework of 1 Corinthians 8:1 to 11:1 as following Christ in loving servitude, Paul's introducing of his apostleship is described as a combination of an example and a defense. He utilizes the agon motif to make his point regarding his own sacrifices. To him self-control (enkrateia) has a finite meaning: to relinquish certain liberties and rights for the sake of his mission in Christ, the identity of the church and the perseverance of his fellow believers. Church leaders can take heed of this necessity for restriction of personal liberty in response to the views of others.

\section{INLEIDING}

Kerklike leierskap was nog altyd in die spervuur. Soms is dit die leierskapstyl, dan weer die leierstruktuur of die teologie van leiers wat onder fel kritiek moet deurloop. Baie kere gaan dit oor die kerkleier as voorbeeld vir die 'gewone' Christene in die kerk. Aangesien kerkleiers meermale gesien word as die 'gesig' van die kerk, word die kerk se identiteit telkens gekoppel aan die persoon van kerkleiers - ten goede of ten kwade.

Onder leiding van die Gees het skrywers in die Woord van God aspekte van kerklike leierskap geboekstaaf wat betekenisvol rigting kan gee vir kerkleiers in hulle benadering en hantering van hulle leiersrol. Ek is van mening dat die apostel Paulus by uitstek ' $n$ menslike voorbeeld gestel wat met groot vrug in die kerk van vandag nagevolg kan word. In die Pauliniese geskrifte is daar talle gedeeltes waarop gefokus sou kon word, maar die verhoudingskrisis wat daar tussen die apostel en die gemeente in Korinte ontstaan het, werp lig

1 Navorsingseenheid, Departement Nuwe Testament, Universiteit van Pretoria. 
op baie fasette van kerklike leierskap. Ek gee eers kortliks aandag aan hoe leierskap in die breë konteks aangesny word. Om egter hierdie artikel nie te wydlopend te maak nie, gaan ek verder slegs fokus op 1 Korintiërs 9:24-27, veral om die besondere vorm van selfbeheersing wat daar aan die orde kom op kerklike leierskap van toepassing maak.

\section{DIE BREË RAAMWERK VAN PAULUS SE ARGUMENT IN 1 KORINTIËRS 8:1 - 11:1}

Paulus skryf hierdie brief voor Pinkster in $55 \mathrm{nC}$ vanuit Efese (Thiselton 2000:31-32)2. Hy gebruik die geleentheid, wanneer hy antwoord op vrae wat die Korintiërs aan hom gestel het, om hulle aan te spreek en te onderrig. Deurgaans is sy kerklike leierskap in die prentjie. Die verdeeldheid wat in die eerste drie hoofstukke aan die orde kom, het juis daarmee te doen dat sy apostelskap onder druk gekom het. Sy argument is dat die gemeente ' $n$ gebou van God is waarbinne elkeen ' $n$ spesifieke rol speel deur te bou op die regte fondament wat hy as apostel gelê het. Die fondament is Jesus Christus (3:9b-21). Hierdie stelling lê ten grondslag van Paulus se etos in die hele brief. Dis nie verniet dat Schrage sy opskrif by hoofstuk 1:18 - 2:5 soos volg formuleer nie: "Das 'Wort vom Kreuz' als Grund und Kriterium von Gemeinde und Apostel” (Schrage 1991:165). In hoofstuk 4 fokus hy op apostelskap en beklemtoon veral die apostels se tipe gesag en hoe baie hulle moes ly en ontbeer. Sy gesag is die van ' $n$ geestelike vader wat in sy persoonlike optrede en leierskap ' $n$ navolgenswaardige voorbeeld stel (verse 14-16). Hy sluit die hoofstuk af deur hulle voor die keuse te stel van watter kant van sy geestelike vaderskap hulle verkies die straffende of liefdevolle kant (verse 18-21). Gebaseer op hierdie vaderlike leierskap, spreek hy hulle etiese optrede en vrae daarna aan (hoofstukke 5 en verder). Sy leierskap word deurgaans in hierdie hoofstukke gebruik om sy etos in die gemeente te bevorder en, omgekeerd, het sy etos ' $n$ bepaalde invloed op hoe sy leierskap daar uitsien.

2 Hy vat al die verskillende daterings van die brief kortliks saam. Ek aanvaar dat die brief, soos ons dit voor ons het, 'n eenheid is. Fee (1987:15-16) kom tot die slotsom dat sogenaamde teenstrydighede in elk geval eksegeties uitgesorteer kan word. 
Die kerk in Korinte was Hellenisties met 'n Joodse minderheid. Die meerderheid van die gelowiges was van die onderste deel van die sosio-ekonomiese spektrum afkomstig, hoewel daar enkele gegoede families was wat ook lidmate was. Dit het gebeur dat die rykes patronaatskap aanvaar vir huisgemeentes. Nadat Chow die rol van patronate binne die Korintiese gemeente ondersoek het, kom hy tot die slotsom: "Paul...had been challenged by some rich and powerful patrons in the church partly on grounds that he did not look like an apostle since he worked to support himself and refused to accept financial support from the church, that is, from them" (Chow 1992:113-120). Hy meen dat die sinkretistiese milieu wel 'n godsdienstige verklaring bied vir die teologiese standpunte van die Korintiërs, maar dat die sosiale realiteite daaragter - en veral die rol van patronaat-kliënt verhoudinge in die kerk - 'n groter rol gespeel het as wat akademici toegee. As mense uit die heidendom het hulle hulle Hellenistiese lewens- en wêreldbeskouing laat inspeel in hulle Christelike geloof. Dit het nog steeds meegespreek in die bepaling van hulle etiese waardes.

Paulus se brief spreek hierdie teologiese en etiese bedreigings van die kerk aan, én in die proses kom sy én die Korintiese leierskap ook duidelik onder die loep. Terwyl hy geensins huiwer om sy gesag oor die gemeente te probeer uitoefen nie, doen hy dit nie met ' $n$ patriargale onderdrukkende styl nie. Hy was oortuig dat hulle lojaliteit nie behoort te lê by magtige beskermhere of selfs by hom wat Paulus is nie, maar primêr by God in Christus (Chow 1992:170). In sy optrede en boodskap was hy die makelaar van God se patronaatskap (Joubert 1995:216).

Paulus se oogmerk is die opbou van God se geloofsgemeenskap in 'n gemengde gemeenskap (Malan 1991:215-6). Die goue draad, wat deur die hele brief loop, is ' $n$ oproep tot elke gelowige om te lewe vir ander deur te sterwe aan jouself. Dit is waarom dit gaan in 'n lewe in gemeenskap met Jesus Christus wat vir die mens gesterf het en deur God opgewek is. Omdat God uit liefde Jesus Christus gestuur het om vir mense te sterf, moet die gelowige vanuit sy liefde vir God en sy medemens lewe. Die opstanding van Jesus maak so 'n lewe van selfverloëning moontlik: Hy wat Paulus is, soek nie sy eie belang nie, maar dié van baie ander, sodat hulle gered kan word. Daarin moet die kerk sy voorbeeld navolg, soos hy die voorbeeld van Christus navolg, want dit is die wese, die identiteit van die kerk. 
Binne hierdie raamwerk fokus Paulus in hoofstuk 8:1 tot 11:1 op die vraag wat die Korintiërs aan hom gestel het of hulle vleis wat aan ' $n$ afgod geoffer of in die slaghuis te koop is, kan eet. Horrell is van mening dat die vraag afkomstig is van die sosiaal meer prominente deel van die gemeente wat gemeen het hulle het die reg (ejous i a) om offervleis die eet omdat hulle die insig en kennis het dat daar geen afgode bestaan nie (1996:106 ev). Paulus se antwoord behels dat hy die Korintiërs teregwys oor hulle siening dat hulle kennis hulle die reg gee om te maak soos hulle wil, want hulle maak ' $n$ grondliggende fout om te dink dat kennis die basis van Christelike gedrag is: liefde is inderdaad die gelowige se grondmotief (8:1-3). Tot by hoofstuk 11:1 gaan Paulus dan voort om met ' $\mathrm{n}$ verskeidenheid van voorbeelde te illustreer dat gelowiges se regte en vryhede in fyn balans met hul liefde vir hul God en medegelowige hanteer moet word. Deelgenootskap binne die gemeenskap van die gelowiges staan in duidelike kontras teenoor individualisme wat op eie behoeftes en belange fokus (De Wet 2005:342 ev). Gemeenskap binne die gemeente hou noodwendig in dat die medegelowige se probleme ook joune is, want indien jy hom benadeel, benadeel jy eintlik jouself (De Wet 2005:372 ev). Natuurlik is hulle deur die Here se verlossingswerk bevry, maar juis daarom word hulle deur liefde binne die geloofsgemeenskap gedring om hulle vryhede en regte met inagneming van ander se belange te beoefen. Liefde, en nie kennis nie, is die primêre motivering binne die geloofsgemeenskap en dit bou die medegelowige op (8:2).

Anders as wat die Korintiërs gedink het, is hierdie die betekenisvolle basis van die sosiale etos van die Christelike beweging. In hulle geval wys Paulus hulle daarop dat wat ' $\mathrm{n}$ mens eet regtig tog nie so belangrik is dat dit die medegelowiges se saligheid in gedrang behoort te bring nie (8:7-13). In sy eie geval bring sy liefde vir sy medemens, soos dit tot uiting kom in sy drang om aan hulle die evangelie van Christus te verkondig, mee dat hy met graagte sy apostoliese regte en vryhede een kant tot skuif (9:123). Hy waarsku hulle hoe gevaarlik afgodery kan wees (10:1-22) en vat die gedeelte saam deur te wys op die verband tussen liefde vir jou medemens - en dus die inagneming van sy gewete en belange en die eer van God (10:31) (Horrell 1996:146). In die proses huiwer Paulus geensins om homself as ' $n$ voorbeeld voor te hou nie (10:3311:1), miskien juis omdat sy leierskap en persoonlike optrede in 
gedrang gekom het. Juis vanuit sy etos gebaseer op liefde en opoffering verdedig hy sy apostelskap en -styl.

\section{DIE ROL VAN HOOFSTUK 9 EN SY APOSTELSKAP IN HIERDIE PRENTJIE}

Aan die begin van hoofstuk 9 bring Paulus skielik sy persoonlike vryheid en apostelskap in die prentjie in. Tog pas dit binne die breë raamwerk van die antwoord oor offervleis (o a De Wet 2005:328). Die vraag is net of sy hantering van sy apostelskap maar net gewoon ' $n$ goeie voorbeeld is van die altruïstiese opoffering waarvan hy in hoofstuk 8 gepraat het. Of was sy leierskap in gedrang in dié gemeente en moes hy dit fel verdedig? Vir die tema van hierdie artikel is dit belangrik om dieper hierop in te gaan.

Paulus begin die hoofstuk met konfronterende retoriese vrae en onverwagse skerpheid wat dui op sterk emosies (Fee 1987:394, 416). Hy argumenteer dat hy wel die reg het op materiële ondersteuning, net om daarna net so passievol ("Ek gaan liewer dood!" - vers 15) te sê dat hy nie van die reg gebruik gemaak het nie. Hy doen dit om homself as ' $n$ skerp voorbeeld aan die 'sterkeres' in Korinte voor te hou van wat hy in hoofstuk 8 van hulle verwag: "The self-lowering of the apostle is a radical model for the strong in Corinth... Paul's example is of one who has deliberately given up status and freedom, becoming a slave of all and becoming weak" (Horrell 1996:208209). Voeg hierby die wyse waarop hy homself onderhou - deur handearbeid te verrig - dan is dit goed moontlik dat daar van die Korintiërs was wat sy optrede persoonlik as beskamend beleef het, omdat dit impliseer dat hulle nie hulle apostel behoorlik kon ondersteun nie (Fee 1987:404).

In die proses van ' $\mathrm{n}$ voorbeeld stel, begin dit egter duidelik word dat hier iets meer op die spel is: dit gaan nou ook baie duidelik oor ' $n$ verdediging van sy optrede: "Questions about the genuineness of Paul's apostleship seem to lie somewhere beneath the criticism to which Paul here responds" (Horrell 1996:210 vgl ook Fee 1987:399400). Sy leierskapstyl is so radikaal anders dat dit 'n steen des aanstoots vir die 'sterkeres' onder die Korintiërs is. Daar was beslis konflik tussen Paulus en die sosiaal meer prominente lidmate van die gemeente in Korinte. Hoofstuk 9 gee vir ons 'n blik op hoe die konflik ontwikkel het rondom Paulus se beoefening van sy apostelskap. Hulle was bekommerd oor die beeld en leefstyl van ' $n$ apostel, terwyl sy selfbeskrywing en selfverstaan van sy apostelskap 
gewoon ' $n$ verlengstuk is van die etos en optrede waartoe hy die Korintiese gemeente aanspoor. Dit is duidelik ooreenstemmend: sy apostelskap is ' $n$ spesifieke beliggaming en uitdrukking van sy etos (Horrell 1996:204-5).

Hy is nie ' $n$ apostel wat van bo af beheer nie, maar wat homself tot slaaf maak van dié wat hy lei. Voeg hierby dat hulle beledig is deur sy verwerping van hulle patronaatskap, en dit is duidelik dat hy in hoofstuk 9 nie net ' $n$ voorbeeld van homself maak nie, maar ook sy leierskapstyl verdedig. Ons moet in gedagte hou dat leierskap noodwendig deurgaans in dié brief 'n onderliggende motief is. Immers, die Korintiese patronate het hulle Hellenistiese siening van leierskap volledig in die gemeente ingebring.

Ons moet egter Paulus se verdediging van sy leierskapstyl reg beoordeel. Hy is nie besig om sy persoonlike gesag te verdedig nie. Hy is juis met ' $n$ argument besig waarin hy sy medegelowiges in Korintiërs vermaan om, uit liefde vir hulle medegelowiges, hulle eie belange ondergeskik te stel aan dié van ander. Paulus sal dit tog nie ru onderbreek om eers sy eie belange te verdedig nie! Nee, veel eerder is die styl deurgaans dat Paulus geensins ' $n$ streng en waterdigte afbakening tussen sy eie persoonlike belewenis en sy voorskrifte aan die gemeente handhaaf nie. Let maar op hoedat hy, onder andere in $2: 1,3: 1,4: 6,4: 16,5: 4,7: 7,8: 13$ en 10:33, gemaklik en sonder huiwering sy persoonlike optrede te berde bring midde-in ' $n$ argumentasie. So pas het hy in 8:13 sy eie uitgangspunt bereidheid om regte en vryhede op te offer ter wille van die welsyn van ' $n$ broer in die geloof - as voorbeeld vermeld het. Daarom gaan hy logies voort om 'n reg en vryheid waaroor hy beskik, waarvan die opoffering in sy lewe die grootste moontlike selfdissipline verg, op die tafel te plaas. Verder sluit Paulus die gedeelte in vers 27 ook af deur sy persoonlike deelhebbing aan die evangelie te koppel aan ander gelowiges s'n. Wanneer hy onmiddellik daarna en sonder waarskuwing die Israelitiese voorbeelde van afgodsdiens te berde bring (die oorgang in 10:1 is minstens net so abrup as die in 9:1), bly sy oogmerk nog steeds dat die gelowige ander se belange hoër moet ag as sy eie. Daarom stel Paulus in sy samevatting (10:23-11:1) dit weer klinkklaar: “'n Mens moet nie sy eie voordeel soek nie, maar dié van ander" (10:24) en (met homself weer as voorbeeld) "Ek soek nie my eie belang nie maar dié van baie ander, sodat hulle gered kan word" (10:33). 


\section{STRUKTUUR VAN 1 KORINTIËRS 9}

Die struktuur van dié hoofstuk lyk breedweg soos volg:

Vers 1-2: Paulus se persoonlike regte en vryhede as apostel word binne die breër konteks van regte en vryhede van gelowiges op die tafel gesit.

Vers 3-12b: Verdediging van die apostoliese reg op lewensonderhoud.

Vers 12c: Paulus loop as't ware sy punt wat hy later maak vooruit deur te sê dat hulle nie van dié reg gebruik gemaak het nie.

Vers 12d-14: Nog twee argumente ten gunste van die reg op lewensonderhoud word bygevoeg.

Vers 15-18: Paulus maak nie van die reg op lewensonderhoud gebruik nie: hy gee hierdie vryheid terwille van die evangelie prys.

Vers 19-23: 'n Verduideliking van die beginsel wat ten grondslag van die prysgawe van regte lê: uit diensbaarheid aan die evangelie word hy alles vir almal.

Vers 24-27: Met beelde uit die sportwêreld bevestig hy die beginsel om vryhede te ontsê ter wille van ' $\mathrm{n}$ groter doel. Pfitzner noem dit “...the crowning conclusion to 9:1-23” (1967:85).

\section{PAULUS SE GEBRUIK VAN DIE WEDSTRYDBEELD IN 9:24-27}

Daar is min twyfel dat die beeldspraak van hierdie paragraaf deur Paulus aangewend word om sy hele argument van hoofstuk 9 saam te vat en beeldend af te rond. Tog is dit nie so duidelik watter aspek van die agon motief (wedstrydbeeld) die eintlike punt van die vergelyking is nie. Dit is my oogmerk om te demonstreer dat nie die imperatief van vers 24b nie ("Hardloop dan so dat julle die prys kan wen”), maar wel vers 25a (“Almal wat aan 'n wedstryd deelneem, ontsê hulleself allerlei dinge”) die punt van die vergelyking is.

Die wedstrydbeeld is algemeen in Paulus se tyd deur skrywers en sprekers gebruik om ' $n$ verskeidenheid van motiewe te belig. Dit was by uitstek geskik om die essensie en hart van Griekswees te reflekteer. Dit versinnebeeld die Griekse gees van selfhandhawing, menslike strewe en prestasie. Dit is g'n wonder dat die Spele die sentrum geword het van die lewe van die Griekse mense nie. Dié kompeterende gees het nie net op die atletiekbaan te voorskyn getree nie. Prestasies op alle terreine van die lewe is aangeprys sodat die 
totale openbare lewe vir die Griek 'n agon geword het, 'n terrein om alles in die stryd te werp en te poog om uit te styg bo die res (Pfitzner 1967:16 ev).

Toe Paulus vir agtien maande in 50-51nC in Korinte vertoef het, moes hy beslis die Istmiese Spele - wat in $51 \mathrm{nC}$ gehou is beleef het. Van die vier nasionale Speles wat in Griekeland gehou is, was die Istmiese Spele van Korinte, naas die Olimpiese Spele, die tweede grootste, gevolg deur die Pitiese Spele in Delfi en die Nemeïese Spele van Argolis. Daar is in 'n ryke verskeidenheid van sportsoorte meegeding: hardloop, verspring, spiesgooi, diskus, boks, stoei, ruitersport, ensovoorts. Selfs dans-, drink en soenkompetisies is ook gehou! ' $n$ Oorwinnaarskrans was die opvallende eerbetoon vir die wenner - by die Istmiese Spele was die krans van denne- en selderyblare gemaak (Schwankl 1997:175 ev) ${ }^{3}$. Dalk is dit wat Paulus met “"n verganklike oorwinnaarskroon” (vers 25) bedoel.

Maar wat sou Paulus se beweegrede wees om die agon-motief binne hierdie konteks te berde te bring? Joubert is van mening dat “...(a) cultural sensitive understanding of the athletic images in verse 24-27 against the backdrop of the first century Greco-Roman world, will... underscore the fact that the apostle is here primarily engaged in a defense of his honour ... as apostle within the framework of an agonistic situation" (Joubert 2001:58). Paulus plaas sy gesprek met die Korintiërs oor sy apostelskapstyl binne 'n agonistiese raamwerk, vanweë sy strewe na onafhanklikheid. Joubert voer oortuigend aan dat Paulus, binne die patronaatstelsel van destyds, uiters afwysend opgetree het. Toe hy vrywillig afstand gedoen het van sy apostoliese reg om finansiële ondersteuning van die Korintiërs te ontvang, het hy daarmee geweier om in ' $\mathrm{n}$ wederkerige verhouding met hulle te tree. Paulus het dit gedoen omdat hy sy onafhanklikheid as apostel wou behou. Hy wou nie dat die Korintiërs 'n houvas op hom kry en daarmee sy vryheid - om die evangelie ongehinderd te verkondig beperk nie:

He knew that where believers still held on to the GraecoRoman perceptions, one had to give with a view to receiving something back and that these relationships

3 Tog vermeld Papathomas (1997:225 ev) dat daar in die keisertyd professionele atlete was wat van die een Spele na die ander getoer het. Hulle is dan ook weldeeglik finansieel vergoed. 
entailed a variety of reciprocal obligations...The imbalance in social power, inherent in these social exchange relationships, would have seriously compromised his apostolic freedom to preach to all men (9:19-23). Therefore, in order to avoid becoming ensnared in the conventions of reciprocity and deference to benefactors, Paul refused monetary support of the ekklesiai while he was working in their midst (Joubert 2001:66).

Paulus poog, met sy agonistiese skryfstyl, om die sosiaal meer vooraanstaande lidmate van die gemeente in Korinte te laat insien dat in die nuwe Christelike kerk die Grieks-Romeinse oogmerke met die doen van weldade nie meer kan geld nie. Die kerk is wesentlik anders. Hulle moes agterkom dat persoonlike opofferinge ter wille van ander - sonder om iets terug te verwag - vir Christene eervolle gedrag is. Nou is dit skandalig om na materiële vergoeding en openbare aansien te strewe! Hierin is Paulus vir hulle 'n goeie voorbeeld van selfbeheersing.

Maar hoe rym hierdie antagonistiese styl met die hele klem op koinonia, diens en liefde in hierdie drie hoofstukke? Na my mening staan dit nie daarteenoor nie, want Paulus weet dat die lidmate van die gemeente wat hy hier in die oog het, die beste in hulle eie argumentasiestyl aangevat kan word. Die belangrikste punt is egter dat hy die agonistiese skryfstyl juis gebruik om hulle te beskaam sodat hulle ' $n$ nuwe sosiale styl binne die geloofsgemeenskap sal opneem. Dit is ' $n$ handige manier om sy leierskapstyl só suksesvol te verdedig dat dit as ' $n$ voorbeeld vir die Korintiërs kan dien. Mag en status werk nie meer soos in hulle kulturele omgewing nie. Opoffering ter wille van ander - wat dit juis nie verdien nie en wat niks terug kan doen nie - is nou eerbare gedrag.

Met hierdie verstaan van Paulus se gebruik van die wedstrydbeelde in die agterkop, kan ons nou vers 24 tot 27 van naderby ondersoek.

\section{SELFBEHEERSING BINNE HIERDIE KONTEKS}

$\mathrm{Na}$ ' $\mathrm{n}$ wye aanloop maak Paulus hier van ' $\mathrm{n}$ lewensgetroue beeld gebruik om sy punt oor sy eie opofferinge tuis te bring. Vir die Korintiërs was sport ' $\mathrm{n}$ bekende en geliefde belangstellingsveld. So pas Paulus onmiddellik toe wat hy so pas in vers 19-22 oor sy bediening gesê het: vir die Grieke het hy 'n Griek geword om hulle 
vir Christus te wen. Meer nog, die saak wat hy bepleit, kry daarmee sigbaar 'lyf'.

Dit is dan ook juis vanuit dié perspektief dat Paulus se punt van sy vergelyking duidelik word. Nie die wenmotief of die daarmee verbandhoudende oorwinnaarskroon nie, maar die ingesteldheid waarmee die Christelike vryhede en regte benader word, wil hy aksentueer. Teenoor Roetzel (1999:148) - wat meen dat Paulus hier na enkrateia (selfbeheersing) verwys as die kontrole oor vleeslike begeertes as deel van ' $n$ asketiese dissiplinêre plan - is dit duidelik dat Paulus hier besig is om die onderlinge opbouingswaarde van liefde - veral vir die swakkeres - te beredeneer. Dit hou in dat regte en vryhede met groot omsigtigheid hanteer moet word. Hy wil duidelik maak dat vryheid ook kan beteken dat jy van jouself bevry moet word: dat jy ten koste van jouself moet optree (Schrage 1994:372). Om dit te illustreer, het hy sy reg op lewensonderhoud as voorbeeld op die tafel gesit: 'n reg wat hy vrywillig opgesê het sodat sy verkondiging van die evangelie nie benadeel sal word nie. Hierdie opsegging van regte en vryhede met die oog op die groter doel (die eer van God [10:31]) beeld Paulus uit met die metafoor van die sportwêreld met die sentrale punt: pant a egkrat euetai. Daarom dien dit geen doel om afsonderlike betekenisse toe te ken aan al die fasette van die beeld nie. Dit geld veral van die inleidende dele van die beeld (vers 24). Die stadion en die prys moenie vertaal word in terme van die Christelike lewe nie, want dit is slegs noodsaaklike fasette van die hele beeld:

Paul, by pointing directly to the example of the runners in the arena who exert all their strength and energy to become the 'one', sets the stage for the theme of egkrat euet a i which follows. All the endeavours of the athlete are in vain if he has not trained his body and abstained from all that may in any way harm his physical condition. Consequently (v.25) he is prepared to exercise self-control 'in all things' in view of the goal (Pfitzner 1967:87).

Die pant a ejkrateuet a i sluit direk aan by die tema van vryhede en regte wat deurgaans in die drie hoofstukke voorkom (8:9; 9:1, 4, $5,6,12,18,19 ; 10: 29)$. Ook die gedagte van 'alles vir almal' in vers 22 beeld Paulus se hele oogmerk duidelik uit: alles ter wille van die 
evangelie, insluitende die regte gebruik van sy vryhede deur die opsegging van sy regte.

Drie aspekte van die beeld van die sportwêreld bevat die analogiese elemente: die doelgerigtheid, die groter inspanning en die vanselfsprekende onthouding. Soos die sportman, span Paulus en die gelowige alles in om die einddoel te bereik. Die gelowige se toegewyde lewe is beide indikatief en imperatief. Dis terselfdertyd ' $n$ goddelike genadige gegewe én ' $n$ goddelike opdrag en eis. Daarom gaan Paulus sonder moeite oor van die imperatief van "(h)ardloop só dat julle die prys kan wen”, na die indikatief van onthouding. Hy stel die eis aan homself en sy medegelowige om werklik alles te gee - in sy voorbereiding én in sy deelname. Dit het nie ten doel om daardeur self die prestasie van die oorwinning te behaal nie, maar dit is wesentlik aan die evangelie om te dien.

Die keersy van die uiterste inspanning tydens die wedloop is die ontsegginge, die onthoudinge en selfdissipline wat dit voorafgaan. In die ontsegginge kry ons die sportwêreld se parallel van Paulus se nie-gebruikmaking van sy reg op geldelike ondersteuning (vers 12) en sy bereidheid om alles vir almal te word (v22). Schwankl (1997:185) wys daarop dat van die Griekse Olimpiese atleet vereis is dat hy vooraf vir tien maande hom sal onthou van vleis, wyn en geslagsverkeer. Dit gaan om 'n funksionele selfdissipline in diens van 'n groter doel. In die konteks van die sportwêreld dui dit op die ontbering of prysgawe van dinge tydens oefening; om iets nie te doen of te gebruik nie wat skadelik, of minstens nie opbouend nie, vir die liggaam sou wees. Die atleet se doel is om 'n optimum prestasie in die kompetisie te lewer. Met dié doel in die oog, is hy bereid om allerlei voorregte op te offer. In sy normale lewensgang sou hy die voorregte ten volle benut het, maar tydens ' $n$ oefenprogram wat optimale prestasie in die oog het, ontbeer hy vrywillig en met graagte die voorregte ter wille van die groter doel. Die apostel vind hier ' $n$ analogie tussen sy eie ontberinge, ontsegginge, onthoudinge en dié van die atleet in sy sport en die filosofiese askeet in sy morele filosofie.

Paulus se gebruik van enkrateia in hierdie verband het dus ' $n$ duidelike, afgebakende betekenis: dit dra die eenvoudige boodskap oor dat, ter wille van die doel waarna hy strewe, die roeping wat hy van Jesus Christus ontvang het, die spesifieke eie aard en identiteit van die kerk, die opdrag wat hy moet uitvoer om die evangelie te 
verkondig en die voorbeeld wat hy as geestelike leier stel, hy hom onthou van alles wat dit kan belemmer (Vgl Grundmann 1966:342).

Paulus bring sy uitbeelding van sy eie en die gelowige se lewe direk in verband met die verkryging van 'n oorwinnaarskroon. Hy het klaarblyklik iets van ' $\mathrm{n}$ persoonlike beloning in gedagte, maar verre sy dit van hom om sy saligheid afhanklik te stel van sy eie hantering van sy regte en vryhede. Deur sy prysgawe van vryhede en regte word hy ' $n$ deelhebber aan die vrug (vers 23). Louw \& Nida (1988:559) sien dit as “...one who shares jointly with someone else in a possession or relationship, with emphasis upon that which is in common...(that is, '.... in the gospel')". Die "vrug” en "kroon" wat Paulus in gedagte gehad het, is om saam met die gelowiges wat onder sy verkondiging van die evangelie tot geloof gekom het, te kan deel in die verlossing. Sy siening van die oorwinnaarskroon is maar net komplimenterend met wat hy deurgaans in die hoofstuk sê: hy is bereid om baie op te offer om sodoende ander met die evangelie te kan bereik. Sy oogmerk met die prysgawe van vryhede en regte is dus nie selfsugtig of egoïsties nie, maar by uitstek onselfsugtig en altruïsties.

In vers 26 gebruik Paulus twee parallelle beelde uit die sportwêreld om homself as voorbeeld voor te hou. Deur twee begrippe in dieselfde betekenisveld as egkrat euomai, upwpiayw en doul a g wg w', fokus Paulus weer baie direk op die noodsaaklikheid van onthouding en selfdissipline. Eersgenoemde fokus daarop dat jy jou liggaam in die figuurlike sin onder totale beheer hou, met die implikasie van harde oefening en kastyding as deel van 'n streng selfdissipline (Louw \& Nida 1988:751) terwyl laasgenoemde (om iemand 'n slaaf te maak en so te behandel), slegs binne hierdie verband en spesifiek in samehang met eersgenoemde, dui op die onder beheer bring van jou eie liggaam. Saam dui die twee sekondêre beelde op die atleet wat homself dissiplineer en sy liggaam streng beheer, sodat dit sy doelwit wat hy in die oog het, dien (Pfitzner 1967:91 e v).

Met die afsluiting van hierdie paragraaf vervleg Paulus die metafoor en die saak wat dit uitbeeld met mekaar. Uit die metafoor beweeg hy na sy eie en ander se verkondiging van die evangelie en beskryf sy vrees dat, hoewel hy aanvanklik gekwalifiseer het om die evangelie te verkondig, hy nogtans in die oordeel beoordeel sal word dat hy sy roeping nie enduit uitgevoer het soos wat van hom verwag 
is nie (Pfitzner 1967:94 e v). Die klem val, soos trouens in die hele hoofstuk, op die groot verantwoordelikheid wat die verkondiging van die evangelie op sy skouers plaas.

\section{SLOTSOM}

My slotsom oor die saak wat deur die metafoor uit die sportwêreld aangesny word, is dus dat dit in diens staan van Paulus se apologie oor sy apostelskapstyl. Sy grondliggende motief bly steeds die verlossende liefde wat hy van Christus beleef het. Dit dring hom tot diens aan sy medegelowiges. Hy is nie in die eerste plek besig om sy lesers aan te moedig tot die Christelike morele stryd nie. Sy hoofoogmerk is eers om sy optrede en die beginsel van selfonthouding of -prysgawe van regte en vryhede te verdedig. Hy het geweier om hom in ' $n$ wederkerige verhouding binne die patronaatstelsel met die leiers van die kerk in Korinte te betrek. Daarmee het hy sekere voordele vir homself prysgegee. Die onderliggende gedagte is dat die doelwit in die oog verg dat alles opgeoffer moet word wat enigsins die doelgerigte vordering kan belemmer. Indien opsegging van regte en vryhede noodsaaklik is vir ' $n$ atleet, hoeveel te meer vir ' $n$ apostel van die Here wat alles diensbaar stel aan sy verkondiging van die evangelie. Dit beteken nie dat daar nie 'n sekondêre paranetiese oogmerk is nie. Inteendeel, die oogmerk van hoofstuk 9 was juis om die saak van die Korintiërs se hantering van hulle Christelike vryheid onderling - veral ten opsigte van die eet van offervleis - te illustreer deur 'n voorbeeld uit Paulus se eie lewe! Hy wou juis vir hulle help, deur sy voorbeeld van geleefde liefde, om hulle vryheid te balanseer deur ' $n$ onderling opbouende gesindheid van liefde - sodat jy nie jou broer se val veroorsaak nie - daarom het hy sy eie hantering van sy apostoliese vryhede en regte bespreek. Dit is vir hom 'n parallelle, hoewel nie identiese, situasie wat ook gekenmerk word deur vryheid aan die een kant en die noodsaaklikheid tot opskorting daarvan aan die ander kant.

\subsection{Kontekstualisering van etiese gemeenskap en leierskaps- krisis}

Ek meen dat Paulus se hantering van die etiese gemeenskapskrisis in Korinte, soos wat dit saamhang met sy leierskapstyl, wyer betekenis het in die kerk. Paulus kan aan niemand anders as aan homself so goed laat sien wat dit beteken om so roepingsbewus te wees dat jy jou Christelike vryhede en regte met vrymoedigheid opsê nie. Nie 
alleen sodat die ander kan sien dat hy doen wat hy van hulle verwag nie, maar meer nog omdat die Korintiërs hom ken en weet hoe hy leef. So word dit duidelik wat Christelike vryhede en regte in werklikheid beteken: dit waaroor jy beskik en waaroor jy so beheer het dat jy, waar nodig ter wille van die groter doel, dit vrywillig en met vreugde prysgee en opoffer selfs ten koste van jouself. Om Pfitzner aan te haal: "The concrete situation is ... not the same, the immediate goal is not identical, the Agon of Paul is not that of every Christian; but the eventual necessity for restriction of personal liberty is a rule which applies in both cases" (Pfitzner 1967:98). In Paulus se geval was die groter doel die redding van ander. Hy gebruik die begrip selfbeheersing om hierdie gesindheid uit te druk.

Paulus se selfbeheersing illustreer die wesentlike van kerkwees. Hy dien as voorbeeld van 'n praktiese gemeenteleier wat vanuit pastorale oorwegings heel inskiklik en aanpasbaar is. Sy hele argument in hoofstukke 8-11:1 is inderwaarheid gebaseer op ' $n$ liefdevolle opbouingsbeginsel van inskiklikheid en aanpasbaarheid ter wille van die welsyn van die medegelowige en uiteindelik die saak van die Here. Hy wys hoe liefde geleef moet word. Selfs wanneer hy in hoofstuk 9 - binne die raamwerk van die agonmotief as 't ware die stryd met die Korintiërs opneem, is dit juis om die altruïstiese beginsel van opoffering ter wille van ander, te beklemtoon. Gelowiges, en in besonder geestelike leiers, behoort hulleself sekere dinge te kan ontsê. Hulle moet weet dat hulle eer as gelowiges geleë is in die Christelike beginsel van opofferinge ter wille van ander se voordeel:

The opinion and consciousness of any brother or sister is not to be despised or ignored, however weak and foolish they may appear to the strong... Any member of the congregation... must be prepared to amend their practices, to compromise their freedom, in response to the views of others (Horrell 1996:148, 149).

\subsection{Ook vandag eis kerklike leierskap ' $n$ besondere vorm van selfbeheersing}

Omstandighede in die kerk vandag verskil hemelsbreed van die situasie in Korinte in Paulus se tyd. So ook die vorm en aard van kerklike leierskap. Tog is Thiselton reg wanneer hy sê:

If an active engagement between the horizons of the interpreter and those of the text takes place, this process will become 
formative in terms of the reshaping of the interpreter's horizons of understanding (2006:346).

Daar is in hierdie verse vir die gelowige, maar dan ook in besonder vir die hedendaagse kerkleier, sekere etiese waardes wat ten opsigte van leierskapstyl geld, wat tydloos is. Standpunte en debatte behoort vanuit Bybelse funderinge gevoer word en dan op hedendaagse omstandighede toegepas word. Maar nooit kan die styl van ' $n$ spesifieke vorm van selfbeheersing soos Paulus dit destyds in Korinte uitgeleef het, uit die oog verloor word nie. Die onderliggende gedagte is dat die doelwit in die oog verg dat alles opgeoffer moet word wat enigsins die doelgerigte vordering van die saak van die evangelie van Christus Jesus kan belemmer. Indien opsegging van regte en vryhede noodsaaklik is vir ' $n$ atleet, hoeveel te meer vir ' $n$ geestelike leier wat alles diensbaar stel aan sy verkondiging van die evangelie.

Binne die breë Christelike raamwerk van liefde en diens sal telkens binne ' $\mathrm{n}$ spesifieke situasie uitgemaak moet word wat die groter doel is. Prysgawe en opofferinge sal egter geen betekenis hê waar medegelowiges manipulerend daarop aandring nie. Die spreekwoordelike 'swakke broeder' het al in die kerk meermale gepoog om die ganse kerk gyselaar te neem!

Tog staan die beginsel duidelik vas. Paulus se selfbeheersing dra die boodskap oor dat geestelike leiers, ter wille van die doel waarna hulle strewe, die roeping wat hulle van Jesus Christus ontvang het, die spesifieke eie aard en identiteit van die kerk, die opdrag wat hulle moet uitvoer om die evangelie te verkondig en die voorbeeld wat hulle stel, hulle moet onthou van alles wat dit kan belemmer. Om maar liewers vryhede en regte prys te gee ter wille van die akkommodering van broers en susters, is selfbeheersing. Ek dink ek kan met reg sê dat leiers wie se Christelike selfbeheersing só ver strek, daartoe kan bydra dat vasgeloopte debatte opnuut op dreef kan kom, én ook tot verrassende deurbrake kan lei.

\section{Literatuurverwysings}

Bredenkamp, D S M 2001. Enkrateia in die Pauliniese hoofbriewe. Ongepubliseerde doktorale verhandeling. Universiteit van Pretoria.

Chow, J K 1992. Patronage en Power. A Study of Social Networks in Corinth (Journal for the Study of the New Testament, Supplement Series 75), Sheffield: Academic Press. 
De Wet, B W 2005. Koinonia as Teologiese Raamwerk in Paulus se Hantering van die Probleemkwessies in 1 Kor 5-6 en 8:1-11:1. Ongepubliseerde doktorale verhandeling. Universiteit van Pretoria.

Fee, G D 1987. The First Epistle to the Corinthians. Grand Rapids: Eerdmans.

Grundmann, W 1966. eg krat eia, in Kittel G (ed.) Theological Dictionary of the New Testament, vol 2:339-342. Grand Rapids: Eerdmans.

Horrell, D G 1996. The Social Ethos of the Corinthian Correspondence. Interests and Ideology from 1 Corinthians to 1 Clement. Edinburgh: T\&T Clark.

Joubert, S J 1995. Managing the Household: Paul as Paterfamilias in the Christian Household Group in Corinth, in P F Esler (ed.) Modelling Early Christianity: Social-scientific Studies of the New Testament in its Context, London: Routledge, 213-223.

-, 2001. 1 Corinthians 9:24-27: An Agonistic Competition?, Neotestamentica 35(1-2), 57-68.

Louw, J P \& E A Nida (eds) 1988. Greek-English Lexicon of the New Testament. New York: UBS.

Malan, F S 1991. Sinvol Lewe vir Ander: Die Opbou van God se Gemeente in 'n Gemengde Gemeenskap, in Roberts J H, Vorster, W S, Vorster, J N \& Van der Watt J G (reds) Teologie in Konteks, Halfway House:Orion, 187-218.

Papathomas, A 1997. Das Agonistische Motiv 1 Kor 9.24ff. im Spiegel Zeitgenössischer Dokumentarischer Quellen, New Testament Studies 42, 223-241.

Pfitzner, V C 1967. Paul and the Agon Motif. Traditional Athletic Imagery in the Pauline Literature. Leiden: Brill.

Roetzel, C J 1999. Paul. The Man and the Myth, Edinburgh: T\&T Clark.

Schrage, W 1991-2001. Der Erste Brief an die Korinther (EvangelischKatholischer Kommentar zum Neuen Testament), 4 Bande, Zurich: Benziger/Neukirchen-Vluyn.

Schwankl, v O 1997. "Lauft so, daß ihr gewinnt“ Zur Wettkampfmetaphorik in 1 Kor 9, Biblische Zeitschrift 41(1), 174-191.

Thiselton, A C 2000. The First Epistle to the Corinthians (The New International Greek Testament Commentary), Carlisle: Paternoster \& Grand Rapids: Eerdmans.

-, 2006. The Significance of Recent Research on 1 Corinthians for Hermeneutical Appropriation of this Epistle Today, Neotestamentica 40(2), 320-352. 